\title{
The Image of Female Prophets in Ancient Greek and Jewish Literature
}

Ancient Jewish literature contains frequent references to prophets as the human transmitters of allegedly divine messages. ${ }^{1}$ Prophetic figures appear in prose narratives, and texts preserve oracles that are attributed to prophetic figures, as well. Given this rich background, one can say that in some ways prophecy is a characteristic element of ancient Jewish literature. But within the canonical biblical texts that ground this tradition, only four women - Miriam, Deborah, Huldah, and Noadiah - are explicitly referred to as prophets (נביאה).

General treatments of prophets in the Hebrew Bible have on occasion paid attention to the remarkably few references to women prophets found in these texts. ${ }^{2}$ Meanwhile, others have brought female figures into the center of their studies in different ways. Carol Meyers explores the professional women of ancient Israel and argues that women had different functions in that realm, including prophecy. According to Meyers, the work of female prophets was not restricted to proclaiming the divine will; their function may have been broader and may have overlapped with other professionals. ${ }^{3}$ Apart from historical studies, attention has been dedicated to female prophets in studies that focus more generally on women in the context of biblical literature and with particular attention to different biblical authors' views on women and their status. ${ }^{4}$ More recently, the study of classical prophecy has been brought into

1 For the definition see, e.g., M. Nissinen, "What is Prophecy? An Ancient Near Eastern Perspective," in Inspired Speech: Prophecy in the Ancient Near East (eds. J. Kaltner and L. Stulman; JSOTSupp 378; Edinburgh: T \& T Clark, 2004), 17-37, 20; idem, "Gender and Prophetic Agency in the Ancient Eastern Mediterranean and in Greece," in Prophets Male and Female: Gender and Prophecy in the Hebrew Bible, the Eastern Mediterranean, and the Ancient Near East (eds. J. Stökl and C. L. Carvalho; Ancient Israel and Its Literature 15; Atlanta: Society of Biblical Literature), 27-58.

2 J. Lindblom, Prophecy in Ancient Israel (Philadelphia: Fortress, 1962), 96, 202, 330; R. R. Wilson, Prophecy and Society in Ancient Israel (Philadelphia: Fortress, 1980), 155-56, 219-23, 234, 298, 300; J. Blenkinsopp, A History of Prophecy in Israel (2d rev. ed.; Louisville, Ky.: Westminster John Knox, 1996), 51, 117.

3 C. Meyers, Rediscovering Eve: Ancient Israelite Women in Context (New York: Oxford University Press, 2013), 173-77.

4 E.g., J.H. Otwell, And Sarah Laughed: The Status of Woman in the Old Testament (Philadelphia: The Westminster Press, 1977), 155-58; A. Brenner, The Israelite Woman: Social Role and Literary Type in Biblical Narrative (The Biblical Seminar; Sheffield: JSOT Press, 1985), 57-67; P. A. Bird, "Images of Women in the Old Testament," in Missing Persons and Mistaken Identities: Women and Gender in Ancient Israel (OBT; Minneapolis: Fortress, 1997), 41; repr. from Religion and Sexism: Images of Women in the Jewish and Christian Traditions (ed. R. R. Ruether; New York: Simon \& Schuster, 1974); I. Fischer, Gotteskünderinnen: $Z u$ einer geschlechterfairen Deutung des Phänomens der Prophetie und der Prophetinnen in der Hebräischen Bibel (Stuttgart: Kohlhammer, 2002); W.C. Gafney, Daughters of Miriam: Women Prophets in Ancient Israel (Minneapolis: Fortress Press, 2008); H. G. M. Williamson, 
discussion with other fields of study, especially with respect to the broader ancient Near Eastern contexts in which these texts were composed..$^{5}$ In this way, attention to Jewish female prophets has also been recontextualized in a broader cultural environment.

This theme issue of the Journal of Ancient Judaism contributes to the ongoing discussion on female prophets. The present volume contains revised versions of lectures that were offered at the Society of Biblical Literature International meeting in Vienna, July 6-10, 2014. The meeting hosted a special session on Female Prophets titled "The Image of Female Prophets in Ancient Greek and Jewish Literature." The goal of the papers presented in this session was to offer new perspectives on the current discussion concerning female prophets in ancient texts.

On the one hand, the articles in this volume deal with Jewish texts in conversation with the neighboring cultures of the ancient eastern Mediterranean. In this way, they attempt to shed new light on female prophecy in neighboring cultures and further analyze the possible interrelation with the setting of the Jewish texts. On the other hand, special attention has been given to the ancient Greek texts, which remain underrepresented in the comparative studies. While some research on female prophets in the Hebrew Bible and in ancient Near Eastern texts is available, the study of the relationship between Jewish and Greek female prophets is a relatively new area of inquiry. ${ }^{6}$ Moreover, while scholarship often adopts the rabbinic concept that the time of the prophets came to an end after Haggai, Zechariah, and Malachi, some of these articles investigate depictions of female prophets from after that era. These articles introduce new voices into a discussion that is often limited to the Hebrew Bible and the ancient Near East.

Jonathan Stökl, "Deborah, Huldah, and Innibana: Constructions of Female Prophecy in the ancient Near East and the Hebrew Bible," compares Deborah and Huldah to the Mari female prophet Innibana. This character is of particular interest, as she is the only individual female "spokesperson" involved in the cult attested in the preserved texts. Stökl further points out the fre-

"Prophetesses in the Hebrew Bible," in Prophecy and the Prophets in Israel: Proceedings of the Oxford Old Testament Seminar (ed. J. Day; T\&T Clark: London, 2010), 65-80.

5 M. Nissinen and C.E. Carter, eds. Images and Prophecy in the Ancient Eastern Mediterranean (FRLANT 233; Göttingen: Vandenhoeck \& Ruprecht, 2009); J. Stökl, Prophecy in the Ancient Near East: A Philological and Sociological Comparison (CHANE 56; Leiden, Brill, 2012); E. Hamori, Women's Divination in Biblical Literature: Prophecy, Necromancy, and Other Arts of Knowledge (The Anchor Yale Bible Reference Library; New Haven, Conn.: Yale University Press, 2015).

6 E.g., Y.S. Kupitz and K. Berthelot "Deborah and the Delphic Pythia: A New Interpretation of Judges 4:4-5," in Images and Prophecy in the Ancient Eastern Mediterranean, 95-124; A.C. Hagedorn, "The Role of the Female Seer/Prophet in Ancient Greece," in Prophets Male and Female, 101-25. See also the various publications by M. Nissinen, e. g., "Prophetic Madness: Prophecy and Ecstasy in the Ancient Near East and in Greece," in Raising Up a Faithful Exegete: Essays in Honor of Richard D. Nelson (eds. K. L. Noll and Brooks Schramm; Winona Lake, Ind.: Eisenbrauns, 2010), 3-29. 
quent references to women ecstatics and laypeople. These observations serve as a background for the second half of Stökl's study, where he examines the figures of Deborah and Huldah. Following his analysis of the passages that refer to these figures, Stökl notes the shared ability of Innibana, Deborah, and Huldah to access divine will. Despite this shared skill, Stökl finds that the authors' treatment of these figures and especially their means of accessing divine will are different. While the ancient Near Eastern authors seem to value technical divination, the authors of the Hebrew texts remain silent with regard to the specific means by which female prophets would have accessed divine will.

Agnethe Siquans, "She Dared to Reprove Her Father': Miriam's Image as a Female Prophet in Rabbinic Interpretation," discusses rabbinic references to Miriam's prophetic speaking and consequently asks how the rabbinic sources interpreted and valued her as a prophet. Siquans first examines the references to Miriam and her prophecy in the Hebrew Bible. She then turns to GrecoRoman literature as a contextual background for rabbinic interpretation of women's speaking in public. Siquans' analysis of rabbinic literature focuses on two specific passages in b. Sotah and Exodus Rabbah alongside several briefer texts that shed light on how the rabbis viewed Miriam's prophecy. Siquans concludes that rabbinic interpretation of Miriam is twofold. The rabbis generally value Miriam as one of Israel's famous ancestresses. Despite this general appreciation, however, the rabbis criticize Miriam for speaking somewhat openly in a number of texts. Siquans argues that the rabbis at least partly inherited the objections concerning Miriam's public speaking from the surrounding pagan and Christian cultural environments.

Hanna Tervanotko, "Unreliability and Gender? Untrusted Female Prophets in Ancient Greek and Jewish Texts," studies disbelief in the divine messages transmitted by female figures. Her discussion is centered around three texts, composed in the late Second Temple era, all of which portray women in a prophetic role: Liber Antiquitatum Biblicarum, Jubilees, and the Sibylline Oracles. In these three texts, women who access the divine will and transmit the messages to the others are not believed to transmit authentic divine messages. After a careful reading of these passages, Tervanotko looks at the portrayal of the figure of Cassandra, which appears in ancient Greek texts as the disbelieved figure par excellence. Through a comparative reading of the Jewish and Greek sources, Tervanotko asks to what extent the literary purposes assigned to Cassandra can also explain the unreliability that appears to characterize the Jewish female prophets. She concludes that whereas in Greek texts both men and women appear as unreliable prophets, in Jewish texts unreliability appears to be a female characteristic.

Manuela Giordano, "From Gaia to the Pythia: Prophecy Suits Women," focuses entirely on Greek female prophets and thus offers new insights for the study of the ancient Mediterranean area as a cultural context. Gordano analyzes the connection between Gaia, the personified female Earth, her daughter 
Themes, and the priestess Pythia, depicted in Aeschylus' Eumenides in the fifth century B. C.E. Giordano highlights the significance of Delphi as the most well known of the ancient oracles and points out that it was a woman, Pythia, who produced the oracular prophecies and acted as Apollo's priestess there. Giordano argues that as a matter of fact the Greeks understood Pythia to be a successor to earlier female prophets and that the Greeks thought that female voices prophesied from the primordial era on. Many sources link Pythia's legacy with Gaia, by connecting her prophetic skill with the Earth, from which her oracular power was believed to come. Giordano then compares female prophetic voices to women speaking in public in ancient Greece. She emphasizes that as public speech was a male domain in ancient Greece, the powerfully authoritative voice of the Delphic prophetess seems to stand at odds with the role Greek men (or at least fifth century Athenians) assigned to women.

These articles, which draw from the fields of biblical, ancient Near Eastern, classical, and Jewish studies, offer new interdisciplinary insights into women's prophecy in the ancient Mediterranean cultural environment. Stökl highlights the gender ambiguity of the Jewish authors in contrast to the Mari texts, where women prominently performed various prophetic functions. Giordano discusses the understanding of female prophecy in Greek contexts and emphasizes women's central role in the most important oracle, vis-à-vis women's limited possibilities to speak in public. Tervanotko points out how the Greek/ Hellenistic idea of rhetorical persuasion may have influenced the portrayal of certain female figures and how disbelief in prophetic messages appears to be a female characteristic in the Jewish texts (cf. Stökl's conclusion concerning ambiguity). This is in striking contrast to the Greek texts, as demonstrated by Giordano. Siquans argues that Greco-Roman ideas continued to influence the rabbis in the first centuries C.E. and afterwards. Together, the articles demonstrate that while female prophecy appears to have been a wide enterprise in ancient Mediterranean environments, ancient Jewish literature preserves only marginal references to it, and appears to deal with it in a polemical way.

These conclusions encourage scholars to incorporate our specific fields of study into broader frameworks and foster interdisciplinary research. The evidence examined in this theme issue also points toward potential new avenues of study. It urges the scholars to revise our earlier hypothesis concerning women and prophecy and to ask new questions. For instance: why was female prophecy marginalized in the ancient Jewish literature when the surrounding cultures, or at least their texts, are seemingly more at ease with it?

Hanna Tervanotko, University of Helsinki, Guest editor 